\begin{tabular}{|c|c|}
\hline $\begin{array}{l}\text { MINING AND METALLURGY INSTITUTE BOR } \\
\text { UDK: } 622\end{array}$ & $\begin{array}{l}\text { ISSN: 2334-8836 (Štampano izdanje) } \\
\text { ISSN: 2406-1395 (Online) }\end{array}$ \\
\hline UDK: $622.271: 681.325(045)=111$ & doi:10.5937/MMEB1601001V \\
\hline
\end{tabular}

\title{
APPLICATION OF THE UNMANNED AEROPHOTOGRAMMETRY IN MONITORING CONDITIONS AND CHANGES AT THE OPEN PIT MINES
}

\begin{abstract}
In the area of monitoring the spatial conditions and changes at the open pit mines, introduction of aerophotogrammetry with unmanned aerial vehicles significantly improves the effectivity and efficiency of the mining system monitoring in real and extended time. Since this is a relatively new technology, the paper presents our first experiences in the application of unmanned aerophotogrammetry, interesting also from the point of view of implementation into GIS systems.
\end{abstract}

Keywords: open pit mine, aerophotogrammetry, unmanned aerial vehicle

\section{INTRODUCTION}

In order to make the technological advance of aerophotogrammetry with the introduction of unmanned aerial crafts more noticeable, a reminder: photogrammetry as a method of visual measurement through which the shape and position of photographed object reconstructed is almost as old as the photography technology (mid XIX century). Photogrammetric recording can be terrestrial (from the ground), aero photogrammetric (from a plane or helicopter) and satellite. Aerophotogrammetry has developed in parallel with the aviation development, and today this is an almost unavoidable recording technique of the earth's surface. Recording is done from a plane with special measuring cameras, the result of which are the aero photogrammetric recordings, as the sum of visual information about a land surface that is the focus of recording. It is used for making the national maps, cadastre, cadastre-topographic and topography

plans, theme maps, photomosaics, photoplans, orthophoto, etc. In order that the aero photogrammetric recordings can be used in stereo photogrammetric restitution of details, the recording is done with a suitable overlap of details (most commonly, 60\% in length and $25 \%$ cross). Beside the plane of suitable flight characteristics and special cameras, for the classic recording of this type, a pilot, navigator and a cameraman are also hired.

The development of unmanned aerial crafts for civilian purposes is a novelty and is today on the rise, and presents a significant technological advancement in aerophotogrammetry. According to this technicaltechnological concept, the miniature robotic aircraft acts as a plane, pilot, navigator and a cameraman. The miniature highly sophisticated aircrafts, equipped with a propulsion and navigation systems, auto-pilot and a suitable camera, is an equivalent to the classic aero photogrammetric systems.

\footnotetext{
*Mining Institute, Belgrade, Serbia, slobodan.vujic@ ribeograd.ac.rs

** University of Belgrade, Faculty of Mining and Geology, Serbia, aleksandar.milutinovic@ rgf.bg.ac.rs
} 


\section{HALLMARKS OF THE UNMANNED AEROPHOTOGRAMMETRIC TECHNOLOGY}

In the domain of measurement, monitorring of conditions and surface changes, aerophotogrammetry is of inexhaustible possibilities and satisfies a basic condition measurement accuracy and significantly increases the surveillance and management efficiency in long-term and in real time. Considering the current events, development and application trends in this field, it is realistic to expect an increase of professional usage the unmanned aero photogrammetric technology in various areas. The rise of development and market competition for this technology is very noticeable at present. According to prognosis, this technology will have a great influence on employment, new job openings and profits, i.e. in the US alone during the first three years of development, this technology had created 70,000 new jobs and influenced the economy by 13.6 billion dollars.
The idea of unmanned aircrafts is not new. The idea originated from the time of the first air balloons, and was intended primarily for military and espionage purposes. This case repeats the historic rule that military activities and wars never bring joy and welfare, but they always influence innovation and birth of new technologies and discoveries, i.e. during the II World War, the radar, electronic and mechanical computer, rockets, and nuclear reactor were constructed and implemented, or development the global positioning satellite system (GPS) during the seventies. Without going too much into classification and categorization of modern unmanned aircrafts, two basic development directions will be mentioned in terms of control, one relates to the remote control and the second to the autonomous control.

Table 1 Comparative display the basic performances of unmanned aircrafts of two prominent manufacturers

\begin{tabular}{|c|c|c|c|}
\hline \multirow{2}{*}{$\begin{array}{l}\text { Order } \\
\text { No. }\end{array}$} & \multirow{2}{*}{ Performance } & \multicolumn{2}{|c|}{ Aircraft model } \\
\hline & & TrimbleUX5 & senseFlyeBee \\
\hline 1. & Wings & Fixed & Modular \\
\hline 2. & Weight & $2.5 \mathrm{~kg}$ & $0.63 \mathrm{~kg}$ \\
\hline 3. & Wing span & $100 \mathrm{~cm}$ & $96 \mathrm{~cm}$ \\
\hline 4. & Camera & $16.1 \mathrm{MP}$ & $16 \mathrm{MP}$ \\
\hline 5. & Launching method & Catapult & From hand \\
\hline 6. & Flight duration & $50 \mathrm{~min}$ & $45 \mathrm{~min}$ \\
\hline 7. & Landing method & \multicolumn{2}{|c|}{$\begin{array}{l}\text { Autonomously on the underbelly with reverse en- } \\
\text { gine operation }\end{array}$} \\
\hline 8. & Landing area & $50 \times 30 \mathrm{~m}$ & $20 \times 20 \mathrm{~m}$ \\
\hline 9. & $\begin{array}{l}\text { Extreme meteorological } \\
\text { conditions }\end{array}$ & $\begin{array}{l}\text { Winds up to } 65 \mathrm{~km} / \mathrm{h} \\
\text { Drizzle } \\
\text { Temperatures } \\
\text { from }-25 \text { to }+55^{\circ} \mathrm{C}\end{array}$ & Winds up to $45 \mathrm{~km} / \mathrm{h}$ \\
\hline 10. & Ground recording resolution & $2.4-23.9 \mathrm{~cm}$ & $3-30 \mathrm{~cm}$ \\
\hline 11. & Maximum flight altitude & $5,000 \mathrm{~m}$ & $800 \mathrm{~m} \mathrm{[?]}$ \\
\hline 12. & Recording overlap & variable, $80 \%$ standard & $50 \%-85 \%$ \\
\hline 13. & $\begin{array}{l}\text { Planning and surveillance } \\
\text { software }\end{array}$ & Yes & Yes \\
\hline 14. & Data processing software & Yes & Yes \\
\hline
\end{tabular}


A functional categorization of unmanned aircrafts in the area of aero photogrammetry has not been created, but the crafts that are pertinent to the contents of this paper are classified as miniature unmanned models weighing up to several kilograms. This choice of craft is not coincidental, to the contrary, the low cost of acquisition and craft exploitation, satisfaction of functionality requirements, mobility and operation functionality, are the main determining performance criteria for the aerophotogrammetry crafts. According to the flight method, there are aircrafts of plane and helicopter type. In recording of larger surfaces, the aircrafts of the plane type are preferred. In order to illustrate and compare them, Table 1 presents the performance of aerophotogrammetry systems of two prominent and popular manufacturers.

The aircrafts can be launched from hand, or via catapult, Figure 2. Catapult launch does not depend on the skill of the operator, it is safer (the operator is at a distance from the propeller) and is more reliable in terms of ascent angle and ascension speed. The aircraft that are launched from hand are smaller and weigh less, they are more suitable for transport, handling and transport by hand.
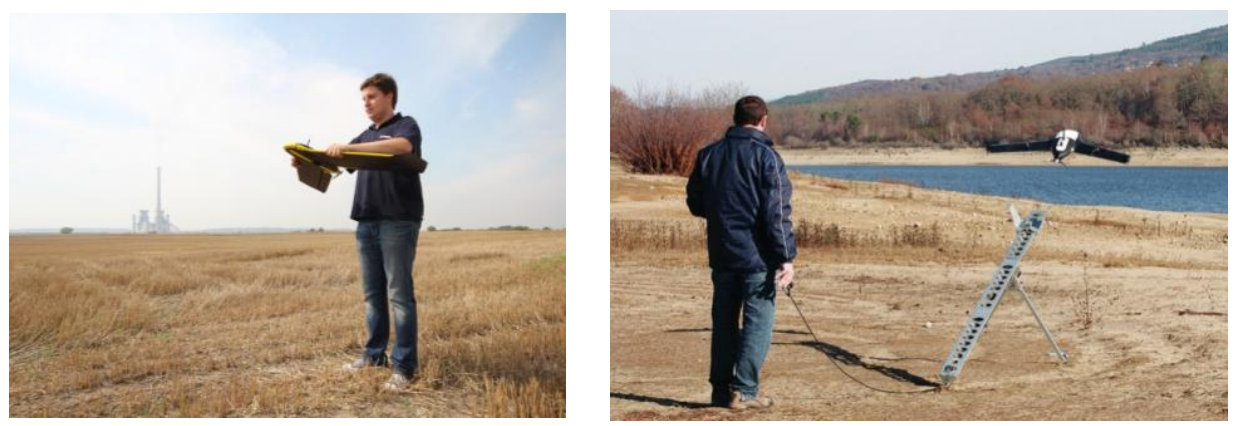

Figure 1 Unmanned craft launch, from hand and by catapult

Aero photogrammetric crafts are controlled using a computer that is integrated in the aircraft or via remote control if necessary. The structure of the unmanned aerophotogrammetry system, besides the aircraft with the camera, propulsion system (battery and electric motor), sensors and GPS, is comprised of: the control system, a system of radio connection with the craft in order to transmit instruction, i.e. flight planning, surveillance and management, software for planning and flight programming and processing and recording interpretation software.

\section{APPLICATION OF THE UNMANNED AEROPHOTOGRAMMETRY TECHNOLOGY}

In comparison to the classic, the advantages of unmanned aerophotogrammetry are: availability, price, safety, efficiency and a wide range of applications. This technology does not require any special training for aero photo recording, which with classic technologies is an exclusive privilege of specialized geodetic and engineering institutions. The technology is available to a wide range of users and is familiar in terms of exploitation. It enables measurement of difficult, inaccessible or dangerous terrains and objects without risks. Data gathering and 
processing is efficient and does not depend on numerous factors as with classical aerial recording, and is faster than any terrestrial measuring technology.

This technology has great application potential, and even though it is not omnipotent, it does not have strict boundaries of practical uses in measuring, control and monitoring the state of field surfaces, regions and objects. There is a wide range of applications for the unmanned aero photo technology in mining, geology, geo-technology, geo-morphology, geodesics, geophysics, GIS, geography, biology, agriculture, forestry, water industry, construction, traffic, electric industry, urbanism, architecture, archeology, ecology, monitoring and preservation of the environment, spatial planning, land cadastres, safety surveillance, search and rescue operations, etc.

In mining, especially with the open pit exploitation of mineral ores, the unmanned aero photo technology provides an efficient visual surveillance in real time which was not possible until recent times:

- Instabilities in soil shifts (settling, creeping, slipping, sliding, landslides, erosion processes);

- Monitoring of geological research operations;

- Positioning and surveillance of the condition and changes in the exploitation fields;

- Monitoring of the operation dynamic at the open pits and depots;

- Actualization of the condition of the open pits and depots;

- Monitoring of the excavated masses of ore and waste, supplies at the depots etc.;

- Monitoring of the impact on the environment, reclamation activities and landscaping;

- Indication and monitoring of breakdowns;

- Security surveillance;

- Expropriation support etc.

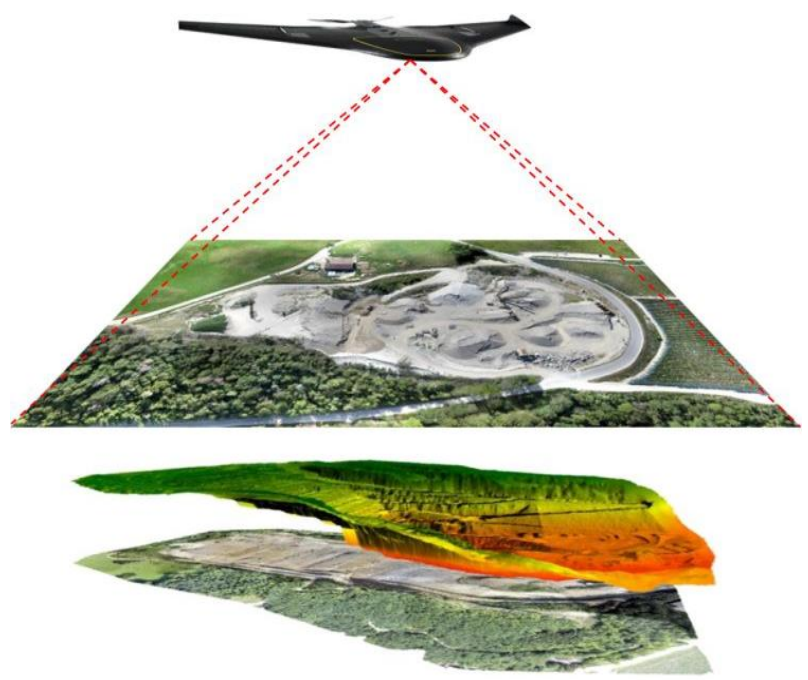

Figure 2 Principal display of the aero photo recording of the open pit and the outcome results (orthophoto and digital model).

The innovation of this technology is obvious, and its importance for surveillance upgrade and management of mining systems, with safety and production results, will be quantified during the time to come. 
Unmanned aero photo technology can be applied in three ways in mining; the first is service by necessity, the second is periodical service, and the third is concession (selling/buying) of technology. The first two models, in investment and exert view, are suitable for mines of small and medium production capabilities, i.e. of modest financial potentials. The third model requires a direct investment of 25 to 60 thousand dollars and expert training, and is acceptable for large mining systems, however it is still recommended as step two due to the personnel adaptation and application the new technology, it is recommended to use, at least for a while, one of the first two models.
A team of experts from the Mining Institute and Livona of Belgrade had on July $24^{\text {th }}, 2013$ conducted the first aero photo recording in Serbia using an unmanned aircraft at the open coal pit Drmno in Kostolac. After a month, the recording was conducted again in order to compare the conditions of operations and excavated masses in the area of the excavated front. A comparative analysis has shown that the results of the aero photo recording via the unmanned aircraft are in correlation and are equivalent with the results of conventional geodetic measurements which are conducted according to regular procedure.
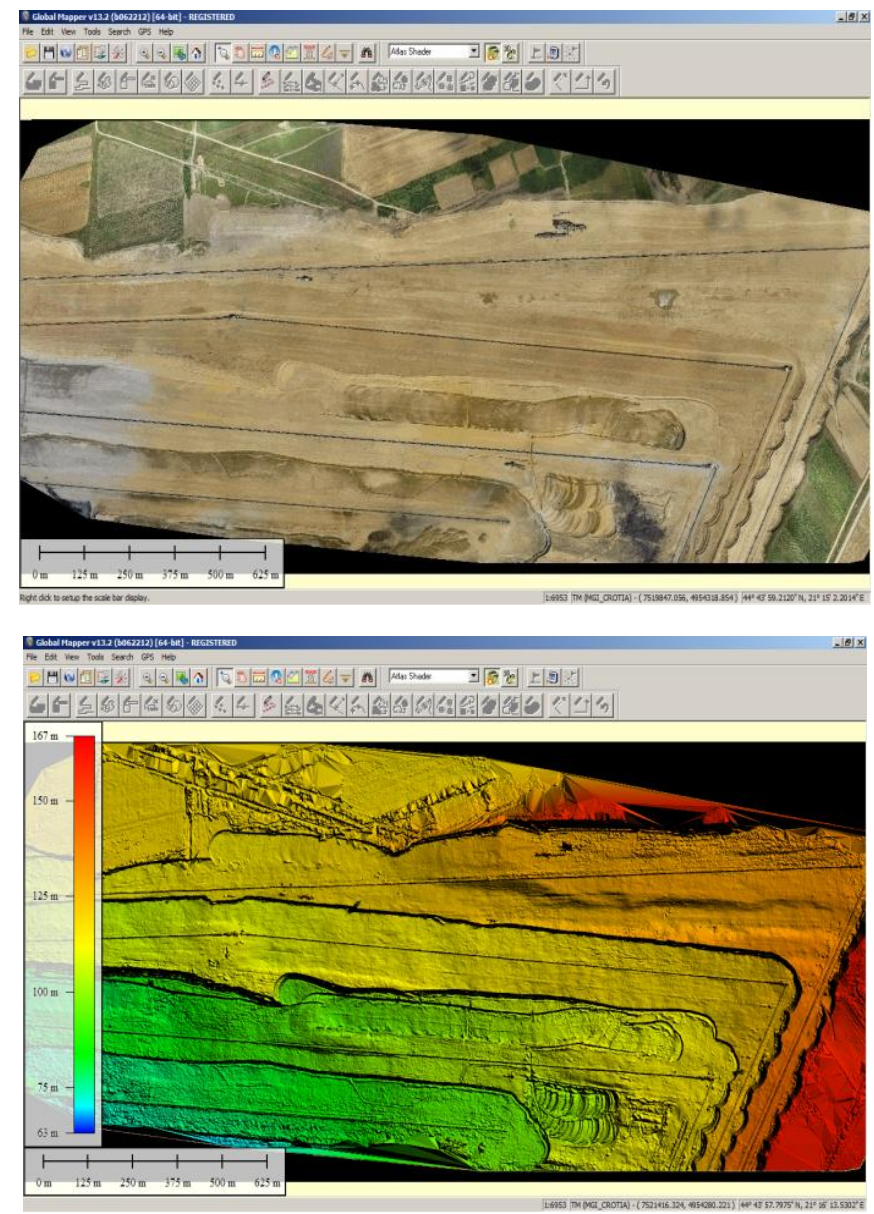

Figure 3 The recorded area of the excavated front of the open pit of Drmno, orthophoto and digital model, July $24^{\text {th }}, 2013$ 
The results obtained are not only a confirmation of the validity of the unmanned aerophotogrammetry technology, but also of its practical uses in mines of great spatial operations such as the coal open pit of Drmno.

The team has conducted experimental test recordings of the open pit of Stražilovo in Sremski Karlovci and of the terrain between the future open pit of Srednja strana and the Special nature reserve of Slano Kopovo in Novi Bečej in 2013. The results in these conditions were identical to the results of the recordings at the open pit of Drmno.

\section{CONCLUSION}

The advantages of the unmanned aero photo technology in comparison to the conventional photogrammetry technologies lie in lower cost, constant availability and accessibility. The significant comparative advantage of the unmanned aero photo technology also lies in the fact that it does not require specialized personnel for photogrammetry, pilots, navigators and other assisting personnel. It can be expected that with further advancement and develop ment of unmanned aero photo technology, the advantages will be even greater.

\section{REFERENCES}

[1] Adžemović Lj., et al., Unmanned Aerophotogrammetry Systems, presentation at an expert gathering GPS and GIS, organized by Livona 1.l.c. from Belgrade, 14.01.2013, Belgrade (in Serbian)

[2] Vujić S., Mining and Measurement Synergy, introductory presentation at the Expert gathering on the application of unmanned aircrafts in mining and geology, organized by the Mining Institute 1.1.c. of Belgrade and 1.1.c Livona of Belgrade, 30.10.2013, Belgrade. (in Serbian)

[3] Vujić S., Application of Unmanned Aircrafts in Mining and Geology, introductory presentation at the expert gathering GPS and GIS, organized by Livona 1.1.c. of Belgrade, 14.01.2013, Belgrade. (in Serbian)

[4] http://www.itnews.com.au/News/3022 40, australian-miners-send-drones-towork.aspx

[5] http://www.multirotorforums.com/ showthread.php?14840-Laser-microdrone-takes-mining-to-a-new-level 